\title{
Influence of feeding on the production of honey bee queens during the dearth period under Nasr City conditions - Cairo
}

\author{
A. E. Hussain ${ }^{1}$, I. A. Shehata ${ }^{1}$, G. F. Abo Laban ${ }^{1}$, and A. A. Al-Ayat 1,* \\ ${ }^{1}$ Plant Protection Department, Faculty of Agriculture, Al-Azhar University, Cairo, Egypt \\ * Correspondence author email: adelabouyahyia@azhar.edu.eg (A. Al-Ayat)
}

\begin{abstract}
Under Nasr City conditions, honey bee colonies exposed to dearth period, which occurs in the summer season. This work was designed to overcome the bad effects of this period by feeding on fresh and stored pollen (for one and two years) to study the effect of pollen on queen rearing of ( $\mathrm{F}_{1}$ hybrid Carniolan and Italian) by measuring the food consumption, success grafting and mean of virgin queen body weight. During the dearth period from 31 Jul. to 15 Aug. 2019, twenty-four honey bee colonies of the same strength (12 Carniolan and 12 Italian) were distributed as follows, three treatments and control (three replicates for each) from every race. Food consumption mean by the two tested honey bee races from fresh pollen, was $(143.7 \mathrm{~g})$ while it was (121.7 and $113.5 \mathrm{~g})$ from the stored pollen for one year and for two years respectively in the same period. The Italian race consumed higher quantity from different diets than the Carniolian race and the nocturnal consumption was more than diurnal one. The successful grafting percentages mean for the two tested races resulted from feeding on fresh pollen, the stored pollen for one-year, stored pollen for two years and control were (66.2, 39.9, 37.9 and 24.3\%) respectively. The mean of the Carniolian and Italian newly emerged virgin queen weight resulted from feeding on fresh pollen $(0.224 \mathrm{~g})$, while those resulted from feeding on stored pollen for one year and two years were $(0.217$ and $0.202 \mathrm{~g})$ respectively. The mean of the Carniolian and Italian newly emerged virgin queen weight of control was $(0.185 \mathrm{~g})$. The Italian newly emerged virgin queen had a larger weight mean than Carniolan one.
\end{abstract}

Keywords: Stored pollen, honey bee, queen, fresh, weight, dearth period, food consumption.

\section{INTRODUCTION}

Honey bee colonies are highly dependent upon the availability of floral resources from which they get the necessary nutrients to their development and survival. The honey bees, are essential to the functioning of natural and agricultural ecosystem (Adham 2000; Ahmet and Hakan 2013).

Pollen is the sole protein food of honey bee colony harvested by bee foragers in their natural environment. The presence of pollen in the nest is essential for normal colony development and for regular growth and development of the brood. Brood rearing is a major factor in apiary production and affected by colony feeding on nature pollen and nectar, (Roman 2006).

Colony development, reproduction, population size and food reserves are the major criteria to measure the success of honey bee colony surviving in different regions (Paxton and Echagarreta 1997). They are affected by many environmental factors, (Harbo 1986; Chinh et al., 2005). In honey bees, floral nectar containing carbohydrates and stored as honey, is the energetic supply of individuals and pollen provides most of the nutrients required for their physiological development (Alaux et al., 2010).

During the shortage or complete absence of pollen, or in the presence of only poor-quality pollen, beekeepers often feed colonies of honey bees with either pollen substitute (with no pollen) or supplement (with pollen) diets (Saffari et al., 2006).

The pollen substitute diet and pollen are equality accepted by the bees. The pollen substitute diet is thus, as highly palatable as natural pollen and easily provided as patties to colonies in standard hives (Saffari et al., 2004).

The possibility of improving the efficiency of beekeeping by providing proteinaceous feed lies, in part, in the development of an effective pollen substitute to feed the colonies when pollen is scarce (Zahra and Talal 2008), especially in preparation for early nectar flows (Skubida et al., 2008). Providing proteinaceous feed to stimulate colony strength would then help, in maximizing honey production and crop pollination, to overcome pesticide damage and resistance to parasites and diseases, and for package-bee production flows (Skubida et al., 2008).

The queen rearing is one of the major objectives of apiaries especially for the commercial beekeepers, and it is the main factor to beekeepers there is only one queen in honey bee colony. It is known that economic characteristics of the honey bee colony are dependent mainly on the quality of its queen (Harris 2009).

The queen quality in turn, depends on the genetic, the environmental factors, the breeding 
conditions and queen rearing methods (Hoopingraner and Farrar, 1959; Nagi 1984; Zedan 2002; Taha, 2005; John et al., 2011).

The most important factors affecting quality of queen are rearing period and grafting methods. She was recommended to be raised when the weather is warm, drones are plentiful, nectar and pollen are rich in terms of quality and productivity and mating rate are at the optimum levels. (Kaftanoglu and Kumova 1992; Genc 1997).

The aim of this work, study the effect of feeding on fresh pollen, stored pollen for one year and stored pollen for two years on queen rearing during the dearth period, which occurred in the summer months, in which both pollen and nectar are absent, by studying the following parameters: Food consumption, Success percentages of grafting and Mean of virgin queen body weight.

\section{MATERIALS AND METHODS}

This study has been carried out at the apiary of plant protection Department, Faculty of Agriculture, Al-Azhar University, Cairo, Egypt.

This study was carried during the summer season (from 31 Jul. to 15 Aug./2019). Twentyfour honey bee colonies of equal strength (12 Carniolan and 12 Italian), distributed as follows:

Three treatments and control (three replicates for each) from every race.

\section{Procedures}

The power of each colony was Seven combs covered with bees (four sealed brood combs plus three honey and pollen combs) + plastic feeder. Breeding frames have three strips arranged in three different locations (upper, middle, lower), each strip carrying 16 plastic cups. The breeding frames is exposed to the breeding colony two hours before the grafting to polishing. Choosing the parent colony of the Craniolan and Italian bee hybrid to lay the eggs between the folded brood frames to force the queen to lay eggs and follow up until the hatching is completed three days later.

The fourth day is the first larval instar (larvae of one day age). The queens of the breading colony were removed for 48 hours. The grafting began 48 hours after the queens was removed from the colonies. The effect of feeding on each of fresh pollen, stored pollen for one year and stored pollen for two years on queen rearing during dearth period by measure the following parameters:

\section{Food consumption.}

Diurnal and nocturnal food consumptions were calculated for all tested pollen.

\section{successful grafting percentages.}

Successful grafting percentages were calculated after 48 hours in three different locations (upper, middle, lower) of grafting.

\section{Mean of virgin queen body weight.}

The queen cell was placed under a hemisphere cage after the end of the ninth day of the grafting until the newly emerged virgin queen, and finally it was taken and weighed.

\section{Statistical analysis}

Data were subjected to analysis of variance (ANOVA) using "COSTAT" computer statistical program. Mean values were compared using Duncan's multiple range test, (Duncan 1955).

\section{RESULTS AND DISCUSSION}

\section{Food consumption.}

The results in Table (1) Show that the highest consumption mean by the two tested honey bee races recorded from fresh pollen, was (143.7g) with the consumption rate $(96.2 \%)$ followed by the consumption from the stored pollen for one year $(121.7 \mathrm{~g})$ with consumption rate $(81.2 \%)$, the lowest food consumption occurred from stored pollen for two years (113.5g) with consumption rate $(75.7 \%)$.

The Italian race consumed (65.7g) with consumption rate $(43.8 \%)$, from different tested pollens, while the Carniolian race consumed (60.6g) with consumption rate $(40.4 \%)$.

Consumption quantity in the nocturnal period was (84.7g) with consumption rate $(56.5 \%)$, higher than diurnal one $(41.6 \mathrm{~g})$ with consumption rate $(27.7 \%)$. Statistically there was a significant difference between the effect of fresh pollen and each of other treatments. On the other hand, there was a significant difference between control and stored pollen. 
Table 1. Mean of food consumption by honey bee from different tested pollen (in g) / colony at Nasr city during summer season the period from 31/7- 15/ 8/2019.

\begin{tabular}{|c|c|c|c|c|c|c|c|c|c|}
\hline \multirow{2}{*}{$\begin{array}{c}\text { Treatments } \\
\text { Diets }\end{array}$} & \multicolumn{3}{|c|}{ Carniolan } & \multicolumn{3}{|c|}{ Italian } & \multicolumn{2}{|c|}{ Mean } & \multirow[b]{2}{*}{ Mean / Diets } \\
\hline & Diurnal & Nocturnal & Mean & Diurnal & Nocturnal & Mean & Diurnal & Nocturnal & \\
\hline Fresh & 43.3 & 97.1 & 70.2 & 45.9 & 101.1 & 73.5 & $44.6 \mathrm{~b}$ & $99.1 \mathrm{a}$ & $143.7 A^{*}$ \\
\hline$\%$ & 28.8 & 64.7 & 46.8 & 30.6 & 67.4 & 49.0 & 29.7 & 66.5 & 96.2 \\
\hline Stored 1 year & 37.9 & 77.8 & 57.8 & 43.2 & 84.5 & 63.8 & $40.6 b$ & $81.2 \mathrm{a}$ & $121.7 \mathbf{B}^{*}$ \\
\hline$\%$ & 25.3 & 51.9 & 38.6 & 28.8 & 56.3 & 42.6 & 27.1 & 54.1 & 81.2 \\
\hline Stored 2 year & 40.3 & 67.3 & 53.8 & 38.9 & 80.4 & 59.7 & $39.6 b$ & $73.9 a$ & $113.5 C^{*}$ \\
\hline$\%$ & 26.9 & 44.9 & 35.9 & 25.9 & 53.6 & 39.8 & 26.4 & 49.3 & 75.7 \\
\hline Mean & $40.5 b$ & $80.7 a$ & $60.6 \mathbf{B}$ & $42.7 \mathrm{~b}$ & $88.7 \mathrm{a}$ & $65.7 \mathrm{~A}$ & $41.6 \mathrm{~B}$ & $84.7 \mathrm{~A}$ & 126.3 \\
\hline$\%$ & 27.0 & 53.8 & 40.4 & 28.4 & 59.1 & 43.8 & 27.7 & 56.5 & 84.2 \\
\hline
\end{tabular}

Means in the same row or column with the same small or capital letters do not differ significantly according to Duncan's multiple range test at $5 \%$ probability.

These results are in harmony with those obtained by several authors Ismail (2001) who found that queen rearing began when the brood nest was congested and nectar and pollen were abundant, the maximum queen cups production recorded in March. Keller et al., (2005), Who recorded that the consumption of high-quality pollen induces the development of the hypopharyngeal glands in young honey bee workers. As protein - rich secretions from these glands are an important component of larval food, a direct relationship between pollen supply and brood rearing can be expected. Consequently, the availability of pollen is likely to be a central parameter influencing the development of honey bee colonies. Hassan (2016) During spring and winter seasons, It was found that feeding honey bee colonies on brewer's yeast - chick pea cake supported by pollen as a protein supplement in addition to sugar syrup (1:1) at 3 days intervals for two months of spring season $(25 / 3$ - 29/5/2014) produced more broods with a higher brood rearing rate, stored honey and pollen than the other feeding regimes in the experiment. It was found that commercial cake (1) of pollen substitute or commercial cake (2) of protein substitute caused more broods with a higher brood rearing rate and stored honey and pollen without any significant differences between them. Commercial cake 1 of pollen substitute consists of (sugar + protein + attractive material + vitamins). Commercial cake 2 of protein substitute consists of (sugar + brewer's yeast +
Zea mayes flour + citric acid + cinnamon flour + korkom flour + cuspara flour + digestive material + vitamins).

\section{Successful grafting percentages.}

The data in Table (2) Showed that the general Success of grafting. mean was recorded in Carniolan (43.7\%) while it was $(40.4 \%)$ for the Italian race.

Feeding on fresh pollen gave the highest acceptance percentages $(66.2 \%)$ as mean for the two tested races, while feeding on the stored pollen for one year, stored pollen for two years and control (without feeding) were ( 39.9, 37.9 and $24.3 \%$ ) resp. As respect the strip level, the middle level had the highest acceptance percentage mean $(49.3 \%)$ followed by the lower one (40.1\%), the upper level had the lowest percentage mean $(37.0 \%)$. While a significant difference there was between food consumption means of the two races.

Many authors discuss acceptance percentage. Abd Al Fattah and El-Shemy (1996) found that the plastic queen cups caused significant increase in the acceptance percentage $(84.7 \%)$ than wax $(76 \%)$ when they grafted with young larvae and introduced into queen rearing colony. Gençer, et al. (2000) Found that supplemental feeding of rearing colonies improves the acceptance rate of grafted larvae $(p<0.05)$. Larval age did not affect the acceptance rate. 
Table 2. The effect of different tested pollens on successful grafting percentages mean of grafted queen cups / three colonies in Nasr city during Summer season the period from 31/7- 15/ 8/2019.

\begin{tabular}{|c|c|c|c|c|c|c|c|c|c|c|c|c|}
\hline \multirow{2}{*}{$\begin{array}{c}\text { Treatment } \\
\text { s }\end{array}$} & \multicolumn{4}{|c|}{ Carniolan } & \multicolumn{4}{|c|}{ Italian } & \multicolumn{3}{|c|}{ Mean / Level } & \multirow{3}{*}{$\begin{array}{c}\text { Mean } \\
\pm \\
\text { SEM } \\
\text { Diets }\end{array}$} \\
\hline & $\begin{array}{l}\text { Upp } \\
\text { er }\end{array}$ & $\begin{array}{l}\text { Midd } \\
\text { le }\end{array}$ & $\begin{array}{c}\text { Low } \\
\text { er }\end{array}$ & $\begin{array}{l}\text { Mean } \\
\pm \text { SEM }\end{array}$ & $\begin{array}{c}\text { Upp } \\
\text { er }\end{array}$ & $\begin{array}{c}\text { Midd } \\
\text { le }\end{array}$ & $\begin{array}{c}\text { Low } \\
\text { er }\end{array}$ & $\begin{array}{c}\text { Mean } \pm \\
\text { SEM }\end{array}$ & $\begin{array}{l}\text { Upp } \\
\text { er }\end{array}$ & $\begin{array}{c}\text { Midd } \\
\text { le }\end{array}$ & $\begin{array}{l}\text { Low } \\
\text { er }\end{array}$ & \\
\hline Diets & & & & & & & & & & & & \\
\hline Fresh & 54.2 & 72.9 & 66.7 & $\begin{array}{c}64.5 \pm \\
5.5 \mathrm{a}\end{array}$ & 64.6 & 70.8 & 68.6 & $\begin{array}{l}68 \pm \\
1.8 a^{*}\end{array}$ & 59.4 & 71.6 & 67.7 & $\begin{array}{c}66.2 \pm \\
3.6 \mathrm{~A}\end{array}$ \\
\hline $\begin{array}{l}\text { Stored } 1 \\
\text { year }\end{array}$ & 37.5 & 50.0 & 41.7 & $\begin{array}{c}43.05 \pm \\
3.6 \mathrm{~b}\end{array}$ & 39.6 & 41.7 & 29.2 & $\begin{array}{c}36.8 \pm \\
3.8 \mathrm{~b}^{*}\end{array}$ & 38.6 & 45.6 & 35.5 & $\begin{array}{c}39.9 \pm \\
2.9 \mathrm{~B}\end{array}$ \\
\hline $\begin{array}{c}\text { Stored } 2 \\
\text { year }\end{array}$ & 33.3 & 52.1 & 35.4 & $\begin{array}{c}40.2 \pm \\
5.9 b\end{array}$ & 31.3 & 45.8 & 29.2 & $\begin{array}{r}35.4 \pm \\
5.2 b^{*}\end{array}$ & 32.3 & 49.0 & 32.3 & $\begin{array}{c}37.9 \pm \\
5.5 \mathrm{~B}\end{array}$ \\
\hline Control & 18.8 & 33.3 & 29.2 & $\begin{array}{c}27.08 \pm \\
4.3 \mathrm{~b}\end{array}$ & 16.7 & 27.1 & 20.8 & $\begin{array}{l}21.5 \pm \\
3.02 \mathrm{c}^{*}\end{array}$ & 17.8 & 30.2 & 25.0 & $\begin{array}{c}24.3 \pm \\
3.5 \mathrm{~B}\end{array}$ \\
\hline G. Mean & 35.9 & 52.1 & 43.2 & $\begin{array}{c}43.7 \pm \\
4.6 \mathrm{~A}\end{array}$ & 38.1 & 46.4 & 37.0 & $\begin{array}{c}40.4 \pm \\
2.9 \mathrm{~A}\end{array}$ & $37.0 \mathrm{~B}$ & $49.3 \mathrm{~A}$ & 40.1B & $\begin{array}{c}42.1 \pm \\
3.6\end{array}$ \\
\hline
\end{tabular}

Means in the same row or column with the same letters do not differ significantly according to Duncan's multiple range test at $5 \%$ probability with significant differences between the effect of the three levels.

El-Waseef (2002) stated that the mean number produced queen cups were higher in spring - $1998(16.77 / \mathrm{col})$ and winter $(5.741 / \mathrm{col})$ than the summer $(2.89 / \mathrm{col})$ and autumn $(0.20 /$ col) in the indoor colonies in closed area. While, in the second experimental period (1999-2000) the mean number of produced queen cups were higher in winter $(3.17 / \mathrm{col})$ and summer $(3.48 / \mathrm{col})$ than in spring $(3.00 / \mathrm{col})$ and autumn $(0.29 / \mathrm{col})$ under the same conditions.

Eissa et al. (2012) As respect to the queen cells bar position in dictated the lower position of bars gave the best result of acceptance $(90 \%)$ followed by middle $(76.66 \%)$ then upper bar which gave $(53.3 \%)$ there was no difference of acceptance percent found between grafted lower of larvae aged 1 and 2 days, there was found significant differences of acceptance percent among spring, summer and late summer, whereas. The early summer season was the best period for acceptance of queen cells followed by spring then late summer of period. The tested diets (cakes) did not affect on queen cells, where acceptance percent 41.11$56.60 \%$ and $40-98.88 \%$ for grafted larvae aged 1 and 2 days, respectively.

Khalil (2019) Showed that, the mean of acceptance numbers of grafted queen cups for the colonies treated with diets (a), consist of (2 parts) Wheat Germ + (1 part) brewer's yeast + (3 parts) Sugar Powder. (b), consist of (1 part) Soybean flour + (1 part) brewer's yeast+ $(2$ parts) Sugar Powder. (c), consist of (1 part) Dates paste (Agwa) + (1 part) brewer's yeast + (2 parts) Sugar Powder. (d), consist of (6 parts) wheat germ $+(2$ part) brewer's yeast $+(1$ part $)$ pollen $+(9$ parts) Sugar Powder. and Control, in all grafts were $50.17,40.5,38.6,43.83$ and 35.5 cup/colony, respectively. Generally, the diet (a) produced the greatest number of accepted queen cups followed by diet (d), then diet (b), then diet (c) While, the control colonies produced the lowest number. Statistical analysis showed that, there were significant differences among diet (a) and all treatments. While, there were no significant differences between diet (b) and diet (c).

\section{Mean of virgin queen body weight.}

Data in Table (3) recorded that the highest queen weight as mean for the two races resulted from feeding on fresh pollen was $(0.224 \mathrm{~g})$ while this queen weight mean resulted from feeding on stored pollen for one year and two years were $(0.217$ and $0.202 \mathrm{~g})$ resp. The mean of the Carniolian and Italian newly emerged virgin queen weight of control (without feeding) was $(0.185 \mathrm{~g})$. The Italian newly emerged virgin queen had larger general weight mean $(0.208 \mathrm{~g})$ than 
Carniolan one $(0.205 \mathrm{~g})$. As regard to the level of strip, the middle level gave the largest queen weight mean $(0.210 \mathrm{~g})$ followed by the upper one $(0.207 \mathrm{~g})$ and the smallest one $(0.204 \mathrm{~g})$, resulted from the lower level.

Table 3. The effect of feeding on tested pollens on the mean of virgin honey bee queen weight $(\mathrm{g})$ in Nasr city during Summer season the period from 31-7 to 15-8 /2019.

\begin{tabular}{|c|c|c|c|c|c|c|c|c|c|c|c|c|}
\hline \multirow{2}{*}{ 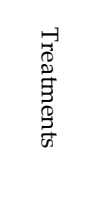 } & \multicolumn{4}{|c|}{ Carniolan } & \multicolumn{4}{|c|}{ Italian } & \multicolumn{3}{|c|}{ Mean / Level } & \multirow{3}{*}{$\begin{array}{c}\text { Mean } \\
\pm \text { SEM/ Diets }\end{array}$} \\
\hline & $\begin{array}{l}\text { Uppe } \\
\text { r }\end{array}$ & $\begin{array}{l}\text { Middl } \\
\mathrm{e}\end{array}$ & $\begin{array}{l}\text { Lowe } \\
\text { r }\end{array}$ & $\begin{array}{l}\text { Mean } \\
\pm \text { SEM }\end{array}$ & $\begin{array}{l}\text { Uppe } \\
\text { r }\end{array}$ & $\begin{array}{c}\text { Middl } \\
\mathrm{e}\end{array}$ & $\begin{array}{c}\text { Lowe } \\
\mathrm{r}\end{array}$ & $\begin{array}{l}\text { Mean } \\
\pm \text { SEM }\end{array}$ & $\begin{array}{c}\text { Uppe } \\
\text { r }\end{array}$ & $\begin{array}{c}\text { Middl } \\
\text { e }\end{array}$ & $\begin{array}{c}\text { Lowe } \\
\text { r }\end{array}$ & \\
\hline Diets & & & & & & & & & & & & \\
\hline Fresh & 0.220 & 0.226 & 0.219 & $\begin{array}{l}0.221 \pm \\
0.002 \mathrm{a}\end{array}$ & 0.224 & 0.229 & 0.222 & $\begin{array}{l}0.225 \pm \\
0.002 a\end{array}$ & 0.222 & 0.228 & 0.221 & $\begin{array}{l}0.224 \pm \\
0.002 \mathrm{~A}\end{array}$ \\
\hline $\begin{array}{l}\text { Stored } 1 \\
\text { year }\end{array}$ & 0.215 & 0.218 & 0.213 & $\begin{array}{l}0.215 \pm \\
0.001 b\end{array}$ & 0.219 & 0.221 & 0.216 & $\begin{array}{r}0.218 \pm \\
0.001 b\end{array}$ & 0.217 & 0.220 & 0.215 & $\begin{array}{l}0.217 \pm \\
0.001 B\end{array}$ \\
\hline $\begin{array}{c}\text { Stored } 2 \\
\text { year }\end{array}$ & 0.201 & 0.203 & 0.198 & $\begin{array}{l}0.201 \pm \\
0.001 \mathrm{c}\end{array}$ & 0.203 & 0.205 & 0.200 & $\begin{array}{r}0.202 \pm \\
0.001 \mathrm{c}\end{array}$ & 0.202 & 0.204 & 0.199 & $\begin{array}{l}0.202 \pm \\
0.001 C\end{array}$ \\
\hline Control & 0.186 & 0.186 & 0.179 & $\begin{array}{l}0.184 \pm \\
0.002 \mathrm{~d}\end{array}$ & 0.187 & 0.190 & 0.183 & $\begin{array}{l}0.186 \pm \\
0.002 \mathrm{~d}\end{array}$ & 0.187 & 0.188 & 0.181 & $\begin{array}{l}0.185 \pm \\
0.002 \mathrm{D}\end{array}$ \\
\hline G. Mean & 0.206 & 0.208 & 0.202 & $\begin{array}{l}0.205 \pm \\
0.008 \mathrm{~A}\end{array}$ & 0.208 & 0.211 & 0.205 & $\begin{array}{l}0.208 \pm \\
0.008 \mathrm{~A}\end{array}$ & $\begin{array}{c}0.207 \\
\text { B }\end{array}$ & $\begin{array}{c}0.210 \\
\mathrm{~A}\end{array}$ & $\begin{array}{c}0.204 \\
\mathrm{C}\end{array}$ & $0.207 \pm 0.008$ \\
\hline
\end{tabular}

Means in the same row or column with the same letters do not differ significantly according to Duncan's multiple range test at $5 \%$ probability.

The same trend of results obtained by Koç and Karacaoglu (2004) Reared honey bee queens in the Aegean region in turkey from the end of March to Sep., they found the betterquality March until the end of April.

Nowar (2011) Found that the highest weight of virgin queen produced by grafting method occurred when the colonies received pollen substitute number 4 in the two years of study. Results also indicated that there were significant differences between used diets and control (sugar syrup only).

Masry et al., (2015) Found that the (81 queens of each genotype) were weighed at emergence and allocated into three groups as : light (110$130 \mathrm{mg}) 45$ queens, medium (140-160 mg) 68 queens, heavy (over $160 \mathrm{mg}$ ) 130 queens and introduced into mating nuclei.

\section{CONCLUSION}

It could be concluded that food consumption ratio, type of honey bee races, stored pollen watch used at pollen supplements and honeybee queen rearing conditions were very important and greatest factors affecting honeybee queen rearing and quality, especially during dearth period.
Newly emerged virgin queen weight is a good indicator of honeybee queen quality which reached to $228 \mathrm{mg}$. that produced by Italian $F_{1}$ hybrid orphan colonies and feeding by fresh pollen, while the highly general mean was $(43.7 \pm 4.6 \%)$ accepted grafted cups for $F_{1}$ hybrid Carniolian. We are carrying out further studies to find the effect of these factors on mating success, availability and their offspring's activities of honeybee mated queens.

\section{REFERENCES}

Abd Al Fattah, M.A., El-Shemy, A.A.M., 1996. Effect of Certain Artificial Queen Rearing Methods on the Quality and Productivity of Queens. J. Agric. Sci., Mansoura Univ, Egypt. 21 (12), 4583-4592.

Adham, M., 2000. Influence of some supplemental feeding on physiological characters and productivity of honey bees. M.Sc. Thesis, Fac. Agric. Assiut Univ., p.159

Ahmet, G., Hakan, T., 2013. Relationship between dead pupa removals and season. and productivity of honey bee (Apis mellifera, Hymenoptera: Apidae) colonies, Turk. J. Vet. Anim. Sci., 37, 462-467.

Alaux, C., Ducloz, F., Crauser, D., lecomte, Y., 2010. Diet effects on honey bee immune -competence. Biol. Lett., $6,562-565$. 
Koç, A.U., Karacaoglu, M., 2004. Effects of rearing season on the quality of queen honeybees (Apis mellifera L.) raised under the conditions of aegean region. Mellifera 2004, 4, 34-37.

Chinh, T.X., Boot, W.J., Sommeijer, M.J., 2005. Production of reproductive in the honeybee species Apis ceranain northern Vietnam, J. Apic. Res., 44 (2), 41-48.

Duncan, D.B., 1955. Multiple range and multiple $F$ tests. Biometrics 11, 1-42.

Eissa, I.S., Hussain, A.E., Shehata, I.A.A., Helaly, K.I.M., 2012. Study of certain factors affecting queen rearing in honey bee colonies on the acceptance rate of grafted queen cells. Annals of Agric. Sci., Moshtohor, 50 (1), 8792.

El-Wasseef, R.A.M., 2002. Ecological and Physiological Studies on Honeybee Colonies under Different Environmental Conditions. M.Sc. Thesis, Fac. Agric., Cairo Univ., p.127.

Genc, F., 1997. The basic beekeeping. College of Agriculture, Ataturk University, Erzurum, p. 188.

Gençer, H.V., Shah, Q.S., Firatli, C., 2000. Effects of supplemental feeding of queen rearing colonies and larval age on the acceptance of grafted larvae and queen traits. Pakistan J. Biol. Sci., 3 (8), 1319-132.

Harbo, J.R., 1986. Propagation and instrumental insemination. In: Rinderer TE (ed) Bee genetics and breeding. Academic Press, Orlando, Fla. pp 361-389.

Harris, J.L., 2009. Development of honey bee colonies on the Northern Great Plains of North America during confinement to winter quarters. J. Apic. Res., 48 2, 8590.

Hassan, S.S.S., 2016. Effect of Supplementary Feeding on Build - up of Honey Bee Colonies. M.Sc. Thesis, Fac. Agric. Ain Shams Univ., p.141.

Hoopingarner, R.C., Farrar, L., 1959. Genetic control of size in queen honey bee. J. Econ. Entomol. 52, 547-548.

Ismail, A.A., 2001. Effect of Some Natural Substances on the Activity and Some Products of Honeybee. M.Sc. Thesis, Fac. Agric. Mansoura Univ. p. 177.

John, W.R., Spooner-Hart, S.R., Anderson, D.L., Wheen, G. 2011. Effects of age, season and genetics on semen and sperm production in Apis mellifera drones. Apidologie 42, 29-38.

Kaftanoglu, O., Kumova, U., 1992. A study on the effects on rearing seasons on the quality of queen honeybees (Apis mellifera L.) raised under Cukurova region conditions. Turk. J. Vet. Anim. Sci., 16, 569-577.
Keller, I.P.F., Imdrof, A., 2005. Pollen nutrition and colony development in honey bees - part II . Bee world J., 33 (4), 125-128.

Khalil, N.M.H., 2019. Effect of Some Food Additives on The Royal Jelly Production in Honey Bee Colonies, Ph.D Thesis, Fac. Agric. Banha, Univ., p.137.

Masry, S.H.D., Abd El-Wahab, T.E., Nadia, M.H. 2015. Origin, weight at emergence of virgin honey bee queens and its effect on acceptance during introduction. Acad. J. Entomol., 8 (4), 174-182.

Nagi, S.K.A., 1984. Studies on Some Factors Affecting Rearing of Queens of Honeybee Apis mellifera (Hymenoptera Apidae) under Shambt Conditions. M.Sc. Thesis University of Khartoum, Sudan.

Nowar, E.S., EL.H 2011. Feeding Technology of Honey Bee Colonies and its Effect on Some Worker's Glands (Apis mellifera L. - Apidae - Hymenoptera). Ph.D. Thesis, Fac. Agric. Moshtohor, Benha Univ. p. 159.

Paxton, C.M., Echagarreta, R., 1997. Comparative colony development of Africanized and European honeybee in (A.M) in low land neotropically. Yucatan, Mexico, J. Apic. Res., 2 (36), 89-105.

Roman, A., 2006. Effect of pollen load size on the weight of pollen harvested from honeybee colonies (Apis mellifera L.). J. Apic. Sci., 50 (2), 47-57.

Saffari, A.M., Kevan, P.G., Atkinson, J.L., 2004. A promising pollen substitute for honey bees. Am. Bee J. 144, 230231.

Saffari, A.M., Kevan, P.G., Atkinson, J.K., 2006. Feed bee balances growth feeding colonies with a nutritious pollen supplement is beneficial. Bee Cult. 134, 30-31.

Skubida, P., Semkiw, P., Pohorecka, K., 2008. Stimulative feeding of bees as one factor in preparing colonies for early nectar flows. J. Apic. Sci., 52, 65-72.

Taha, E.A., 2005. Studies on honeybee (Apis mellifera L.) Unpublished Ph.D. Thesis, Fac. Agric. Tanta Univ. Egypt, p.151.

Zahra, A., Talal, M., 2008. Impact of pollen supplements and vitamins on the development of hypopharyngeal glands and brood area in honey bees. J. Apic. Sci. 52, 512.

Zedan, E.W.M., 2002 Studies on Some Factors Affecting of Production Quality of Honeybee Queens at Giza Region. M.Sc. Thesis, Fac. Agric., Cairo, Univ., Egypt, p. 134 . 


\section{تأثير التغذية على تريبة وإنتاج الملكات خلال فترة القحط تحت ظروف مدينة نصر- الثاهرة}

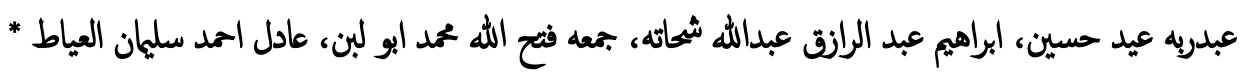

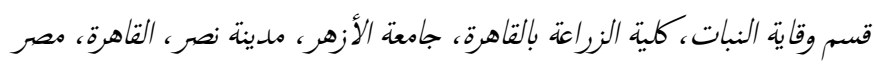

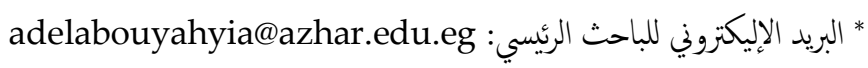

الملخص العربى

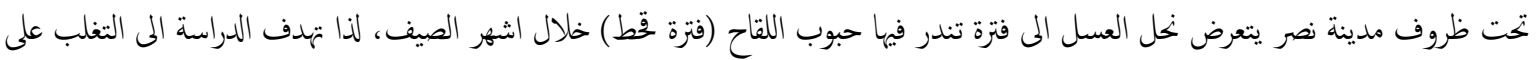

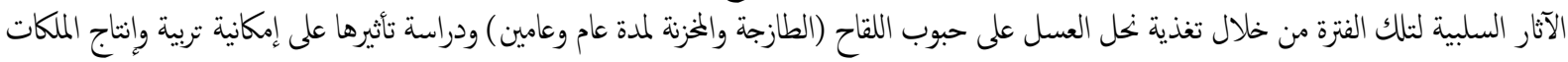

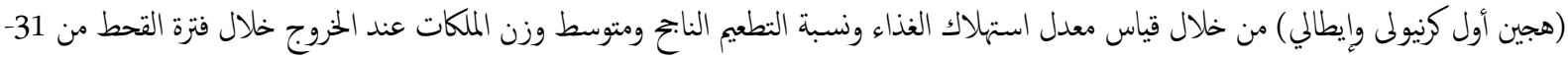

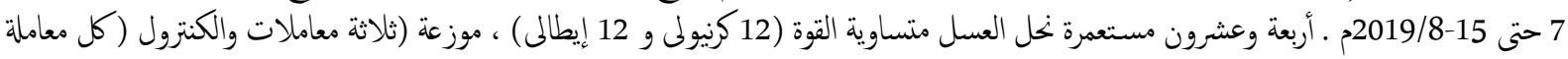

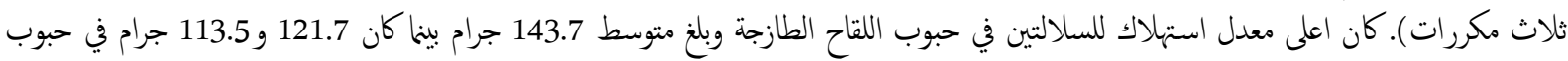

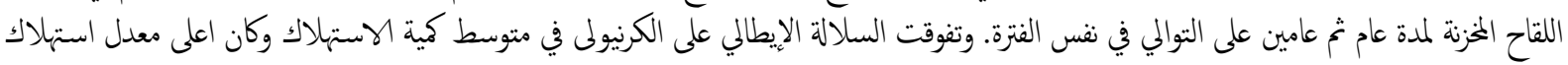

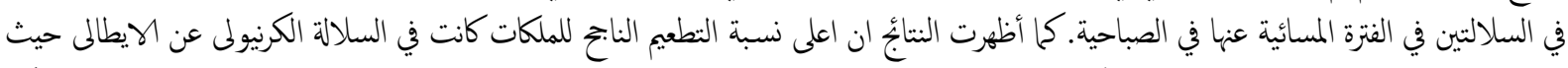

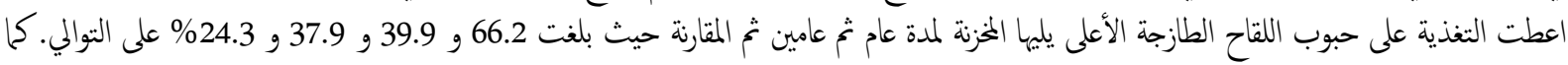

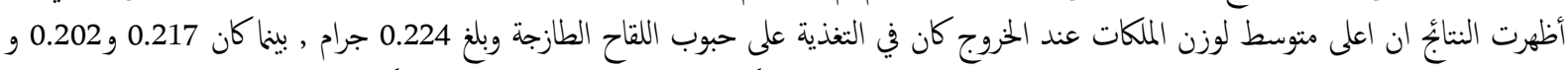

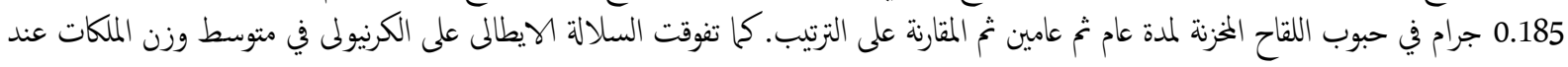

الخروج وبلغت 0.208 و 0.205 جرام على التوالي. الكلمات المفتاحية: حبوب اللقاح الخخزنة، مستعمرة نحل العسل، الملكة، طازج، وزن،فترة الندرة، استهلاك الغذاء. 